\title{
Preparation and Evaluation of Physicochemical and Antimicrobial Properties of Biological Nanostructures Polyolactic Acid / Calcium Oxide by Hydrothermal Assisted Microwave Method
}

\author{
Mohammad Hasan Moshafi ${ }^{1}$, Mehdi Ranjbar*2, Zahra Zeinalizadeh Rafsanjnai ${ }^{3}$, Fatemeh Mehrabi $^{4}$
}

1. Professor of Pharmaceutics Research Center, Kerman University of Medical Sciences, Kerman, Iran

2. Assistant professor of Pharmaceutics Research Center, Kerman University of Medical Sciences, Kerman, Iran

3. Graduate of General Pharmacy, Student research committee, Kerman university of medical sciences, Kerman, Iran

4. Student of General Pharmacy, Student research committee, Kerman university of medical sciences, Kerman, Iran

\section{ABSTRACT}

Background: Today, with the development of human life and the overwhelming fall of antibiotics and uncontrolled bacterial resistance, the need to find materials with antimicrobial effects is felt more than ever. Nanotechnology has created a new opportunity to investigate the antimicrobial effects of nanomaterials.

Materials \& Methods: In this study, using hydrothermal and microwave auxiliary chemicals, polylactic acid / calcium oxide nanostructures were prepared and the physicochemical and microbial properties of these nanostructures were evaluated. Bacterial strains were obtained from the Scientific and Industrial Research Organization of Iran, the collection center of industrial microorganisms.

Results: Physicochemical characterization of optimized polylactic acid / calcium oxide nanostructures showed the antimicrobial effect of nanoparticles on 3 strains gram-positive bacteria Micrococcus luteus (PTCC 1110), Bacillus subtilis (PTCC 1023), Staphylococcus aureus (PTCC 1112) and 4 strains gram-negative bacteria Escherichia coli (PTCC 1330), Klebsiella pneumonia (PTCC 1053), Serratia marcescens (PTCC 1621), Pseudomonas aeruginosa (PTCC 1074). In this study, the observed MIC (minimum growth inhibition concentration) observed for both Gram-positive and Gram-negative bacteria ranged between $0.5<\mathrm{MIC} \leq 8$.

Conclusion: Antimicrobial effect of polyelactic acid / calcium oxide nanostructures was observed on all the mentioned bacteria except $E$. coli. It is recommended to conduct microbial and cellular studies on these nanomaterials.

Keywords: CaO/Polylactic Acid Nanofibers, Gram Positive and Negative Bacteria, Antibacterial Properties

Received: 2020/03/29; $\quad$ Accepted: 2020/06/14; Published Online: 2020/06/18

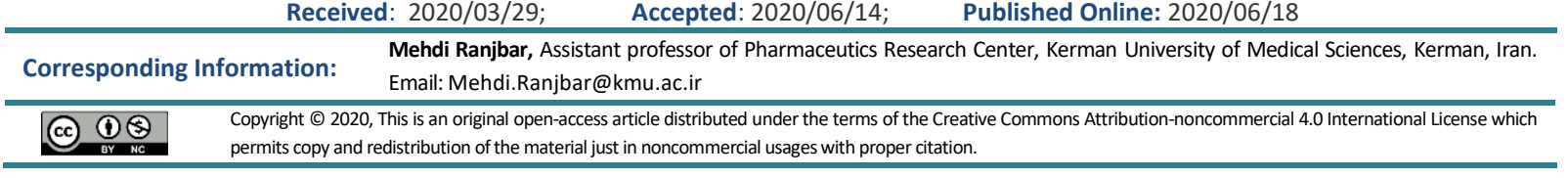

Use your device to scan and read the article online

Moshafi M H, Ranjbar M, Zeinalizadeh Rafsanjnai Z, Mehrabi F. Preparation and Evaluation of the

Physicochemical and Antimicrobial Properties of Biological Nanostructures Polyolactic Acid / Calcium

Oxide by Hydrothermal Assisted Microwave Method. Iran J Med Microbiol. 2020; 14 (3) :224-240

Download citation: BibTeX | RIS | EndNote | Medlars | ProCite | Reference Manager | RefWorks
Send citation to:
8 Mendeley
2 zotero
Hi RefWorks

\section{Introduction}

A biological system can shrink to an infinite size and still maintain its former performance and even add new applications in fact, there are many small cells that are known to be very active in spite of their small dimensions, producing various materials and doing various tasks on their own. This philosophy is one of the starting points for inspiration in nanoscience (1-3). In the recent years, nanotechnology and nanotechnology have begun to make dramatic changes in 
various sciences, especially medical sciences. It can be widely said that the science and engineering of nanotechnology is defined as the design, fabrication, characterization and application of materials and tools that are particles ranging from a few nanometers to hundreds of nanometers in size (46). The overall definition of nanoparticles refers to particles in the range of 1 to $100 \mathrm{~nm}$ (7). These particles are designed to exhibit new, specially controlled properties of their raw material in the usual size, which results from precise control over their fabrication process.

One of the most important issues in drug delivery systems and the science of pharmaceutics is improving drug targeting for specific cells and reducing drug accumulation in cells, as high amounts are not necessary for a good function and might be toxic as well $(8,9)$. This is often because the size of commonly used drug molecules is ten times larger than the size of a red blood cell and so the drug penetrates the cells far less than expected and as a result, we will have to increase the dosage or frequency of use to achieve our goals, which can lead to more toxicity and unintended side effects $(10,11)$. Nowadays, by the use of nanomedicine, targeted drug delivery, reduced toxicity and consequently increased efficacy of antimicrobial drugs at lower concentrations have been achieved $(10,13,14)$. On the other hand, in the treatment of infectious diseases, bacterial resistance to newer antibiotics has always been important, and bacterial resistance will lead to increased doses of antibiotics, increased medication to antimicrobial regimens, increased hospitalization and finally, the mortality rate of hospitalized patients will increase $(15,16)$. Treatment of bacterial infections has been a matter of concern in the past until now $(17,18)$. The use of nanotechnology by numerous approaches has so far been identified as one of the most important ways of overcoming bacterial resistance (19-21, 32). Among the things that can be described as a new generation of antibacterial compounds are nanoparticles containing biopolymers such as chitosan (22), nanoparticles containing metals such as $\mathrm{Au}$ (23), $\mathrm{Ag}$ (24), $\mathrm{Mg}$ (25), Cd (26), Bi and Cu (27). Multiple antimicrobial agents are drug bound to nanoparticles $(15,16)$. The necessity of this research is to create nanostructures based on bio polymeric structure with calcium oxide nanoparticles as one of the cheapest nanoparticles for investigation of antimicrobial properties. Also, the use of chemical imaging and microwave radiation as environmentally friendly and cost-effective methods is one of the unique features of this research work. The aim of this study was to synthesize and optimize particle size of calcium oxide nanoparticles loaded with $1 \%, 0.5 \%$ and
0.25 wt\% in poly lactic acid with $1 \%, 0.75 \%$ and 0.5 wt\% percentage by chemical mimicry and using microwave waves and on 3 gram-positive bacteria evaluation of minimum growth inhibition concentration (MIC) in bacterial strains Micrococcus luteus, Bacillus subtilis, Staphylococcus aureus and 4 gram-negative bacteria Escherichia coli, Klebsiella pneumonia, Serratia marcescens, Pseudomonas aeruginosa.

\section{Materials and Methods}

Among the materials used in this study, $\mathrm{Ca}\left(\mathrm{NO}_{3}\right)_{2} .4 \mathrm{H}_{2} \mathrm{O}$ as a source of calcium and poly lactic acid was purchased from Kimia Exir in Iran, an importer of German-Indian Merck products. The $\mathrm{NaOH}$ used in this study was purchased from Dr. Abidi's laboratory materials company. The distilled water used was provided by the Ab Ban company. To investigate the properties of nanostructures from X-ray machine of Kashan University with (Rigaku D-max C III X-ray) specifications. Scanning electron microscopy (LEO 1455VP) was also used at Razi Metallurgical Research center for imaging nanostructures. Nanoparticle tests were performed at Dr. Ranjbar's pharmaceutical nanomaterials and nanostructures laboratory as well as antibacterial tests at Dr. Moshafi's microbiology laboratory at Kerman university of medical sciences.

\section{Synthesis of Cao/PLA nanocomposites}

For preparation of PLA/CaO nanocomposites, the dry powder of the nanoparticles synthesized from the preceding steps were blended together as follows.

Sediments from calcium oxide weighing 0.25 grams and sediments from polyolactic acid weighing 0.5 grams, sediments from calcium oxide weighing 0.5 grams and sediments from polyolactic acid weighing 0.75 grams and sediments from calcium oxide weighing $1 \mathrm{~g}$ and sediments from polyolactic acid weighing $1 \mathrm{~g}$ were mixed and the synthesized nanocomposites were named $A_{1}, A_{2}$ and $A_{3}$, respectively. The precipitate mixture was refluxed with $10 \mathrm{ml}$ of the $1: 2$ ratios of dimethylformamide (DMF) and water for $30 \mathrm{~min}$ at $50^{\circ}$ $C$ with magnetic stirrer. The mixture was placed in a microwave oven at $300 \mathrm{~W}$ for 15 minutes with 1: 2 onoff cycles and the final precipitate was collected from the filter paper dry. Table 1 shows in vitro conditions for making calcium-containing polyelactic acid nanoparticles.

Table 1. In vitro conditions for the production of $\mathrm{CaO} / \mathrm{PLA}$ nanoparticles

\begin{tabular}{|cc|cccccc|}
\hline Sample & Nanoparticle & PLA $(\mathrm{g})$ & $\mathrm{CaO}(\mathrm{g})$ & $\mathrm{DMF}: \mathrm{H}_{2} \mathbf{O}(\mathrm{ml})$ & $\mathrm{pH}$ & \multicolumn{2}{c|}{ Temp $\left({ }^{\circ} \mathrm{C}\right)$} \\
\hline 1 & $\mathrm{~A}_{1}$ & 0.5 & 0.25 & 20 & $8-9$ & $\mathbf{5 0}$ \\
\hline 2 & $\mathrm{~A}_{2}$ & 0.75 & 0.5 & 20 & $8-9$ & $\mathbf{5 0}$ \\
\hline 3 & $\mathrm{~A}_{3}$ & 1 & 1 & 20 & $8-9$ & $\mathbf{5 0}$ \\
\hline
\end{tabular}




\section{Preparation of Half McFarland Solution}

First, $0.5 \mathrm{~mL}$ of two hydrated barium chloride was prepared at a concentration of $1.175 \mathrm{wt} . \%$ In $1 \%$ sulfuric acid. The constant stirring turned out to be a one-stop suspension. The solution density was measured using optical absorption measurement in spectrophotometer with $1 \mathrm{~cm}$ optical path length equal to 1.5 . The $5 \mathrm{ml}$ solution was poured into coiled tubes the same size as the bacterial suspension tubes and kept in space. The solution was examined before each use for the presence of large particles with the naked eye and then stirred vigorously to create a uniform opacity. Suspension that is similar to the half-McFarland solution for opacity is $1.5 \times 10^{8}$ microorganisms.

Preparation of Muller Hinton agar and Muller Hinton broth culture medium

The $7.6 \mathrm{~g}$ of powder was mixed with $200 \mathrm{ml}$ distilled water and then dissolved by heat and continued heating until the solution was clear. It was then removed by pipette, $18 \mathrm{ml}$ of this medium, poured into large reflux tubes and sterilized by autoclaving at $121^{\circ} \mathrm{C}$ and a pressure of 15 pounds per square inch for 15 minutes. After sterilization, the medium was synthesized with two millimeters of the mixture and the molar Hinton broth medium prepared in various dilutions. It was then removed by pipette, $18 \mathrm{ml}$ of this medium, poured into large reflux tubes and sterilized by autoclaving at $121^{\circ} \mathrm{C}$ and a pressure of 15 pounds per square inch for 15 minutes. After sterilization, the medium was synthesized with two millimeters of the mixture and the molar Hinton broth medium prepared in various dilutions. To prepare this medium, the culture was poured $1 / 2 \mathrm{~g}$ of the powder in $100 \mathrm{ml}$ of distilled water and stirred until the powder was completely dissolved. Then, two millimeters of the prepared medium was poured into small flask tubes and sterilized by autoclaving at $121^{\circ} \mathrm{C}$ for 15 minutes at a pressure of 15 pounds per square inch. Mulberry Hinton agar medium was sterilized in autoclave, poured into $18 \mathrm{ml}$ large test tubes. The dilutions of the $2 \mathrm{ml}$ sample were mixed with a well of melt medium and transferred to a plate. Thus, the final dilutions in the plates were $0.5,1,2,4,8,16,32$ and $64 \mu \mathrm{g} / \mathrm{mL}$. Positive and negative control plates were also prepared on the back of the plates before labeling clearly for the concentration of antimicrobial agent and the culture location of each microbe. Bacteria that were cultured $24 \mathrm{~h}$ in the remaining 7 tubes containing $2 \mathrm{~mL}$ of Müller Hinton broth were microbial suspensions similar to 0.5 McFarland's solution in opium. For this purpose, the loops were sterilized each time by the flame and after that the temperature was lowered to the point that it did not harm the living bacteria, the colonies were removed and dispersed well in a liquid fist medium.

\section{Results}

The X-ray diffraction pattern of a sample of calcium oxide-containing polylactic acid nanoparticles is shown in Figure 1. The peaks that determine and confirm the structure of the nanoparticles are clearly identified in the spectrum. Using the Debar Shear equation, the particle size can be calculated from the following equation:

$$
D_{c}=K \lambda / \beta \cdot \cos \theta
$$

Equation 1

Where $\theta$ is the $X$-ray diffraction angle, $K \lambda$ denotes the wavelength of the beam at a constant whose value is 0.9. And the number in dc estimates the diameter of calcium-containing polyelectric acid crystalline nanostructures at about $150 \mathrm{~nm}$.

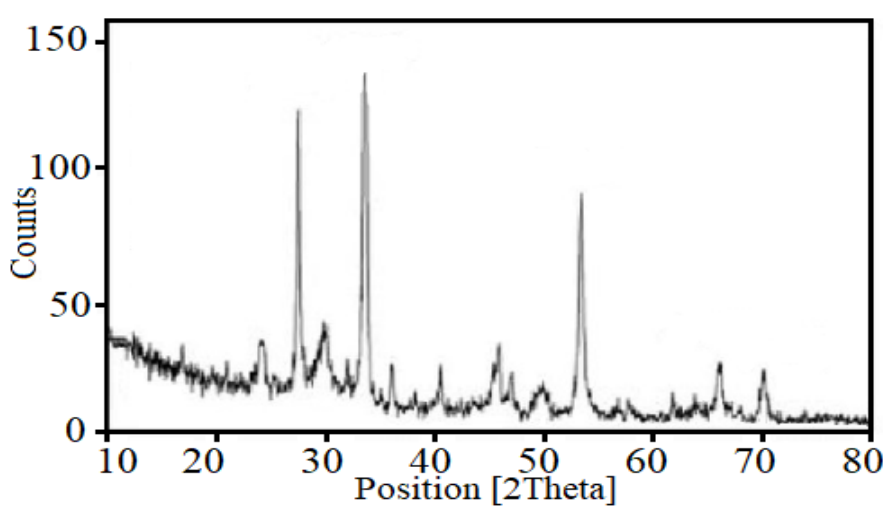

Figure 1. X-ray diffraction pattern of calcium-containing polyelactic acid crystalline nanostructures

To study the exact size of nanostructures, dynamic light scattering (DLS) technique was used to accurately measure the size of the light scattering particles. The nanoparticles prepared are shown in Figure 2, which confirms the approximate size of the nanoparticles in the range of 150 to $450 \mathrm{~nm}$. 


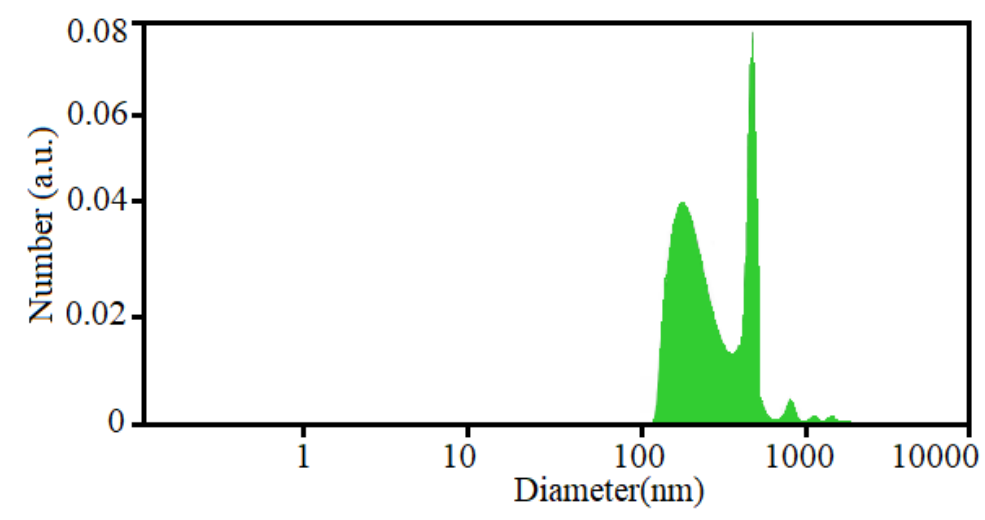

Figure 2. DLS diagram of CaO/PLA nanostructures

To investigate the surface structure and shape characteristics of nanostructures, imaging was performed using scanning electron microscopy. The results of scanning electron microscopy images for samples $A_{1}, A_{2}$ and $A_{3}$ are shown in Figures $3 a, 3 b$ and $3 c$, respectively.
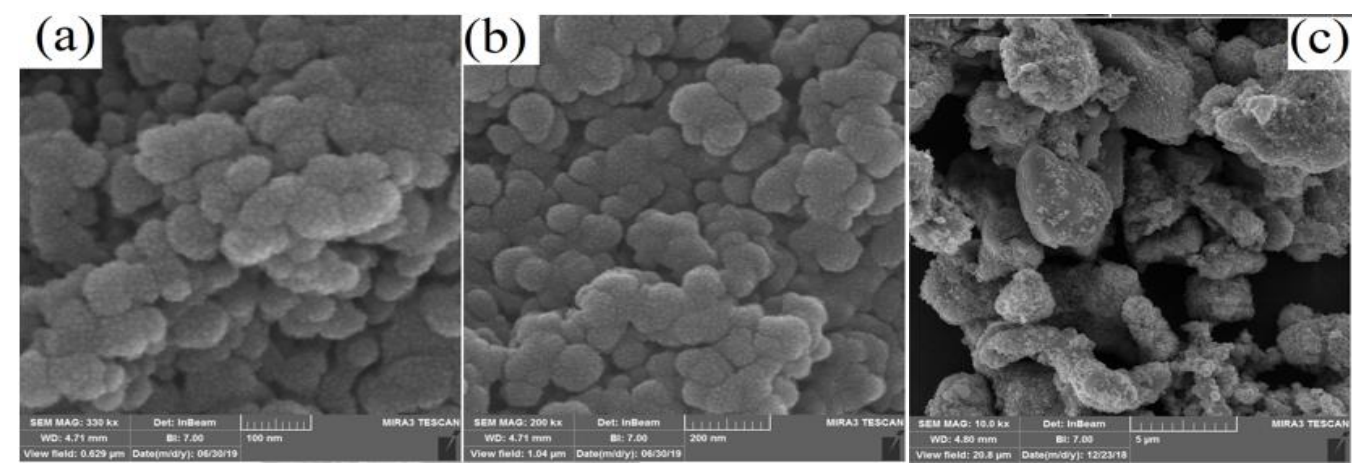

Figure 3. SEM images for $A_{1}, A_{2}$ and $A_{3}$ samples of $C a O / P L A$ nanostructures

Infrared spectroscopy (FT-IR) was used to identify the functional groups and interconnections formed. The infrared spectrum of the nanocomposites is shown in Figure 4. The wavelengths appearing in the region of $3500 \mathrm{~cm}^{-1}$ are related to the $\mathrm{O}-\mathrm{H}$ group hydroxide bonds in the structure. $\mathrm{C}-\mathrm{C}$ bonds appear at wavelengths of about $2920 \mathrm{~cm}^{-1}$ and $2850 \mathrm{~cm}^{-1}$. The $C$
$=0$ bonds present in the polymer base structure of polyelactic acid in the region of $1617 \mathrm{~cm}^{-1}$ are shown in the FT-IR infrared spectrum. The presence of $\mathrm{Ca}-\mathrm{O}$ metal bonds on the polylactic acid substrate in the area below $1000 \mathrm{~cm}^{-1}$ is shown as weak peaks.

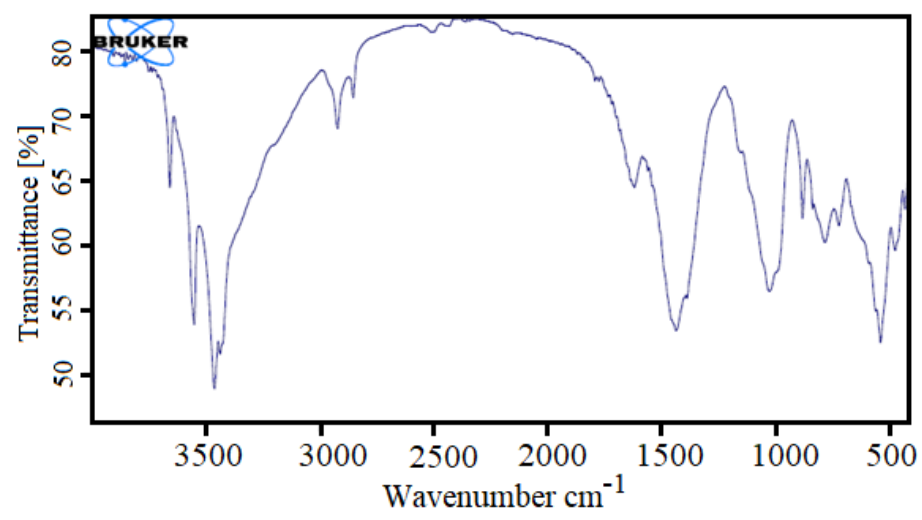

Figure 4. FT-IR spectrum of CaO/PLA nanostructures related to $A_{1}$ 
MIC method was used to investigate the antimicrobial effects of the synthesized compounds. In the MIC results tables, the positive sign indicates growth and the negative sign indicates bacterial growth. Table 2 shows the antimicrobial effects of $A_{1}$ nanoparticles using the MIC method. Also, positive control of the culture medium without microbial inoculation and negative control of the culture medium without microbial inoculation were simultaneously included in all experiments. Figure 5 shows the comparison of the minimum growth inhibitory concentration in all three nanocomposites.

Table 2. Results of standard bacterial growth at 8 different concentrations of $A_{1}$ nanoparticles

\begin{tabular}{|ccccccccc|c|}
\hline Concentration & $64 \mu \mathrm{g} / \mathrm{ml}$ & $32 \mu \mathrm{g} / \mathrm{ml}$ & $16 \mu \mathrm{g} / \mathrm{ml}$ & $\mathbf{8} \mu \mathrm{g} / \mathrm{ml}$ & $4 \mu \mathrm{g} / \mathrm{ml}$ & 2 & $\mu \mathrm{g} / \mathrm{ml}$ & $\mathbf{1} \mu \mathrm{g} / \mathrm{ml}$ & $\mathbf{0 . 5} \mu \mathrm{g} / \mathrm{ml}$ \\
\hline Bacteria & - & - & - & - & - & - & + & + \\
\hline E.coli & - & - & - & - & - & + & + & + \\
\hline K. pneumoniae & - & - & - & - & + & + & + & + \\
\hline S. marcescens & - & - & - & - & + & + & + & + \\
\hline P. aeruginosa & - & - & - & - & - & + & + & + \\
\hline S. aureus & - & - & - & - & - & - & - & + \\
\hline M. luteus & - & - & - & - & - & + & + & + \\
\hline B. subtilis & - & - & - & + & + & + & + & + & + \\
\hline Control + & + & + & - & - & - & - & - & - & - \\
\hline Control - & - & - & & - & & & + & + \\
\hline
\end{tabular}

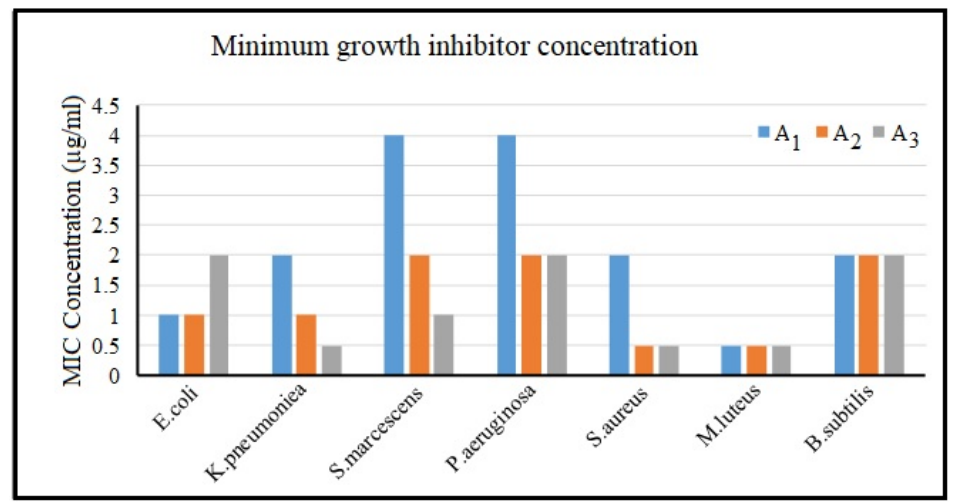

Figure 5. Comparison of growth inhibitory concentration in all three nanocomposites

\section{Discussion}

In recent years, the study on the antimicrobial properties of metal oxide has shown promising results. In this study, the optimum nanostructures were selected by particle size and morphology by structural optimization and phase determination. As can be seen in the light diffraction graph of the $\mathrm{CaO} / \mathrm{PLA}$ crystal nanostructures, the peak has become ring-shaped, confirming the existence of a normal and uniform particle size distribution, which is in clear agreement with the SEM images. The best morphology and uniformity of particle size in $A_{1}$ nanostructures can also be observed through scanning electron microscopy. And this sample is selected as the optimal sample. Investigation of infrared spectroscopic spectra also shows the loading of calcium oxide nanoparticles in polymeric structures. In line with these studies, it has been observed that biopolymeric polymeric nanostructures containing calcium oxide made by chemical and microwave and hydrothermal synthesis have synergistic effects on Escherichia coli strains, Lactobacillus plantarum, Staphylococcus aureus and Staphylococcus aureus. And they have good antimicrobial properties. Ciprofloxacin as a modern antibiotic is effective against most gram-positive and gram-negative microorganisms and is a good positive test for this test. Pseudomonas aeruginosa $0.5 \mu \mathrm{g} / \mathrm{mL} \leq \mathrm{MIC}<$ $1 \mu \mathrm{g} / \mathrm{mL}$, Streptococcus pyogenes $0.5 \mu \mathrm{g} / \mathrm{mL}$ IC MIC < $1 \mu \mathrm{g} / \mathrm{mL}$, Serratia and Klebsiella $0.25 \mathrm{MIC} \leq$, Staphylococcus epidermidis $1 \mu \mathrm{g} / \mathrm{mL} \leq \mathrm{MIC}<2 \mu \mathrm{g} / \mathrm{mL}$, 
Luteus is $8 \mu \mathrm{g} / \mathrm{mL}<\mathrm{MIC} \leq 16 \mu \mathrm{g} / \mathrm{mL}$, bacillus $\mathrm{MIC}>64$ $\mu \mathrm{g} / \mathrm{mL}$, which has fewer positive effects on grampositive bacteria than the results obtained in this study. In 2014, a study on the antimicrobial properties of Copaiba oil showed that pyrrolidone and polylactic acid increased the amount of oil released from the polymer substrate and compared to our work, the results of this article on bacterial strains have received a weaker antibacterial response (28). In 2007, it was observed that a composite made of pectin polymer and polylactic acid produced a heterogeneous biphasic structure that could be observed by electron microscopy and was able to inhibit the growth of Lactobacillus plantarum and concluded that it can be suitable for the packaging industry (29). In addition, another study in 2018 found that the combination of cinnamon, silver nanoparticles, cobalt and antimicrobial agents such as ciprofloxacin increased the antimicrobial effects, therefore, the applications of this polymer in wound healing and drug release can be of more interest (30). Previously used in a study of polycrystalline acid / silicon / calcium carbonate membrane composite containing mercapto groups (PSC-SH) to investigate the antibacterial and stimulating properties of osteoblast activity. This compound owes its properties mainly to the mercapto group, but this study has also shown that polylactic acid polymer can be a significant substrate for material release (31). In the present study, we tried to compare the microbial effects by combining different concentrations of calcium oxide metal nanoparticles in the polymeric lactic acid as a substrate. As the MIC results show, all concentrations had inhibitory effects on the 7 bacterial strains. However, this inhibition did not follow a fixed pattern.

In one study, three different concentrations of calcium oxide nanoparticles were synthesized by microwave and combined with three different concentrations of polymer nanostructures using aqueous solvent-aqueous (hydrothermal) method with specific ratios. Structural and morphological identification were performed with SEM and XRD analysis. All of the synthesized nanoparticles were nanometer sized, but differed in dispersion and surface properties and the particle size distribution followed the normal distribution. The nanoparticle diameter measurements were confirmed by dynamic scattering of light by electron microscopy images. At all concentrations, inhibitory effects of growth on the tested bacteria were observed. There was no difference in the effect of nanocomposite on gram positive and negative bacteria in the tests. For Grampositive Bacillus subtilis bacteria the MIC range remained constant with increasing percentage of calcium oxide and observed no effect of increasing antimicrobial concentration. Also, for gram-negative bacteria Escherichia coli, the antimicrobial effect decreased with increasing percentage of calcium oxide. It seems that this compound can be studied for wound healing formulations.

\section{Conclusion}

Bio-lactic acid / calcium oxide nanostructures with nanoscale sizes are highly capable of destroying nosocomial microbes and can be used as a highly effective synthetic antibiotic in the pharmaceutical industry.

\section{Acknowledgment}

We would like to thank Kerman University of Medical Sciences, Pharmaceutics Research Center as well as the Student Research Committee of Kerman University for their contribution to this research project.

\section{Conflict of Interest}

Authors declared no conflict of interests. 


$$
\begin{aligned}
& \text { مجله ميكروبشناسى يزشكى ايران }
\end{aligned}
$$

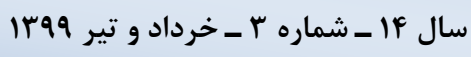

$$
\begin{aligned}
& \text { Journal homepage: www.ijmm.ir }
\end{aligned}
$$

\title{
تهيه و ارزيابى خصوصيات فيزيكوشيميايى و ضدميكروبى نانوساختارهاى زيستى
}

\section{يلى لاكتيك اسيد/كلسيم اكسايد به روش كمكى هيدروترمال و مايكروويو}

\author{
محمدحسن مصحفى'، مهدى رنجبر "广، زهرا زينلى زاده رفسنجانى "، فاطمه مهرابى"
}

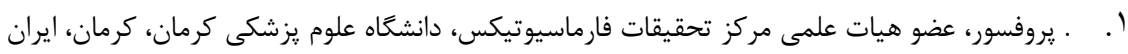

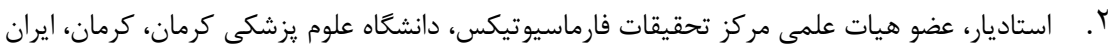

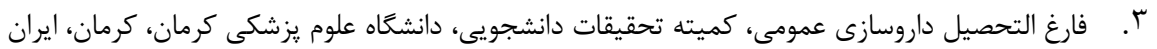

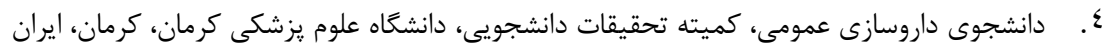

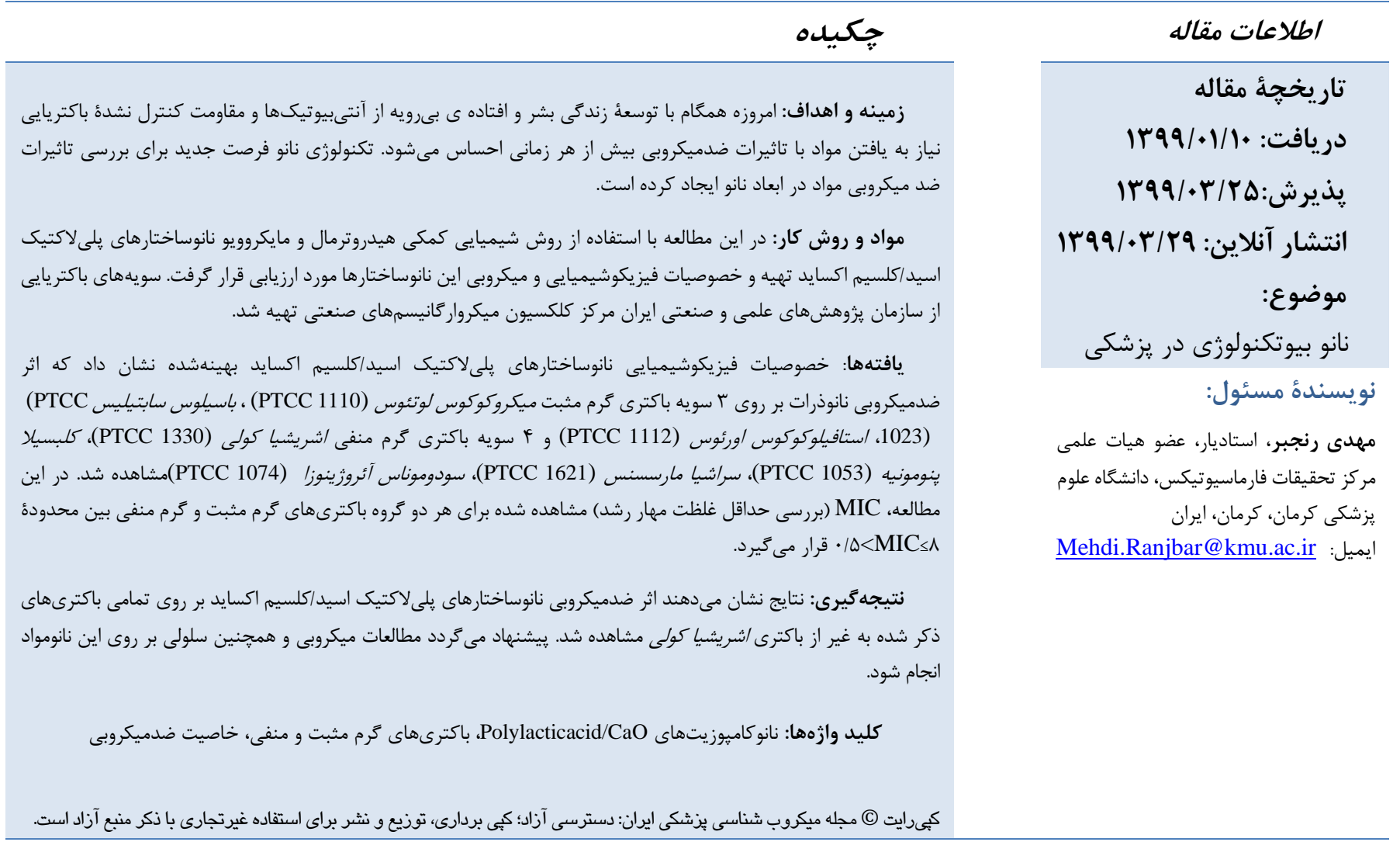

مقدمه

گرفتن در علم نانو محسوب مىشود (1-1). در سال اخير

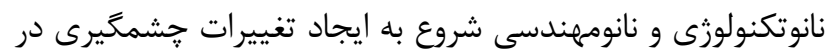
علوم مختلف على الخصوص علوم يزشكى كرده است. بلهصورت گسترده مىتوان گفت كه علم و مهرندسى طراحى، ساخت، تعيين ويزگى و كاربرد مواد و ابزارى كه بهعنوان ذراتى با ابعادى از جند تاند

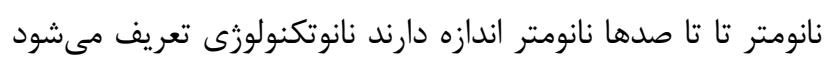

يك سيستم بيولوزيكى مى تواند به اندازهُ بىنهايت كوجك شود

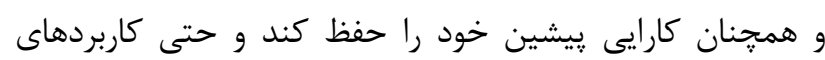

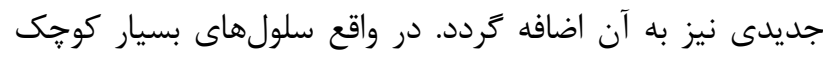

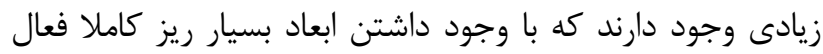

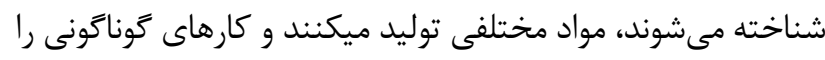
بلتنهايى انجام مىدهند، اين فلسفه يكى از نقاط آغازين براى الرهام 
نانو ذرات اكسيد كلسيم بلعنوان يكى از ارزانترين نانوذرات بهمنظور

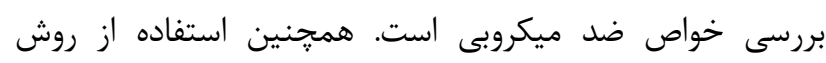

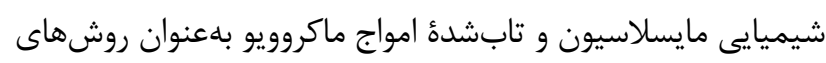

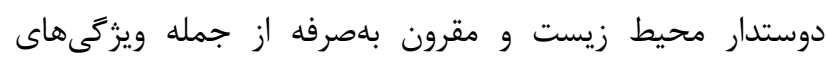
منحصربهفرد اين كار تحقيقاتى است. هدف از انجام اين تحقيق،

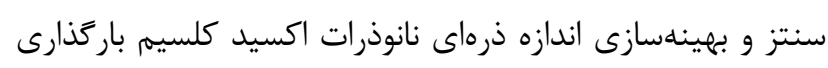

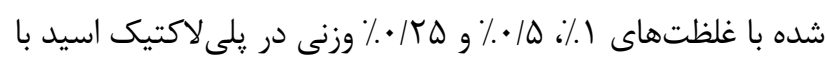

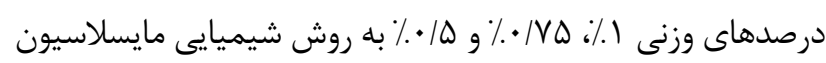

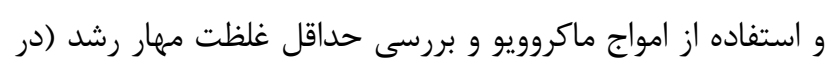
صورت وجود جنين خاصيتى) در سويههاى باكتريايى Serratia marcesenc, staphylococcus aureus, Micrococcus luteus, Bacillus subtilis, Escherichia coli, Pseudomonas, Klebsiella peneumonia

\section{روش يزوهش}

ازجمله مواد مورد استفاده در اين تحقيق شامل Ca(NO $\left.\mathrm{Ca}_{3}\right)_{2} \cdot 4 \mathrm{H}_{2} \mathrm{O}$

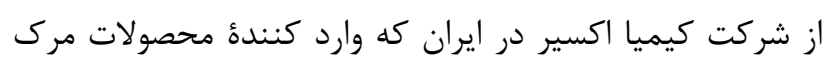

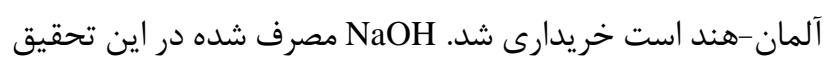
از شركت مواد آزمايشكاهى دكتر عبيدى خريد شريدارى شد. آب آب مقطر

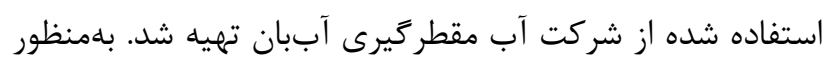

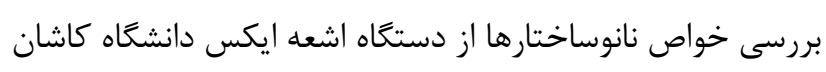

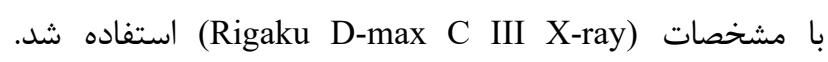
همجنين از دستخاه ميكروسكوٍ الكترونى روبشى با مشخصات (LEO در مركز تحقيقات متالورزى رازى براى تصوير (LEO 1455VP)

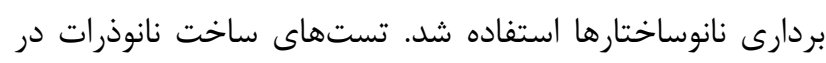

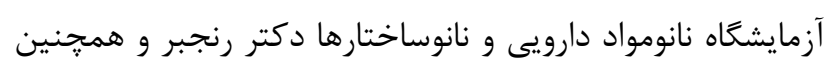

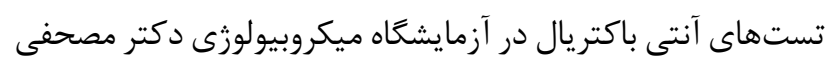
در دانشخاه علوم يزشكى كرمان انجام شد.

\section{روش سنتز نانوكاميوزيت يلى لاكتيك اسيد حاوى}

\section{كلسيم اكسايد}

براى ساخت نانوكاميوزيت PLA/CaO ، يودر خشك نانوذرات

سنتز شده ازمراحل قبل را به ترتيب زير با هم مخلوط شدند. رسوبات حاصل از كلسيم اكسايد با وزن هـ/ • ترم و رسوبات

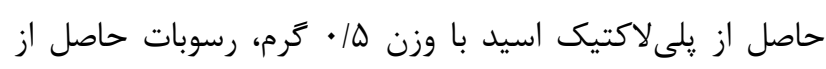

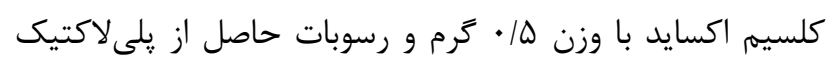

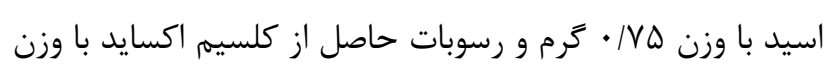

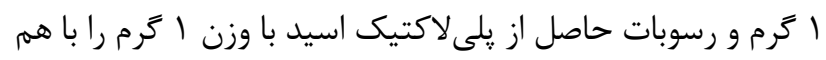

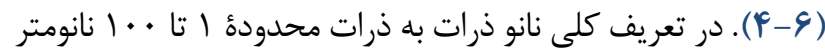

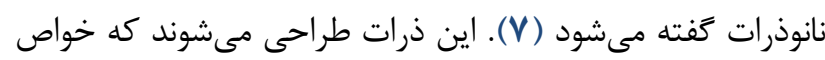

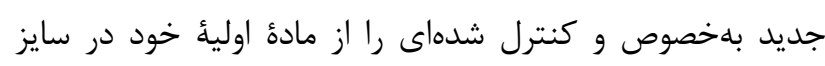

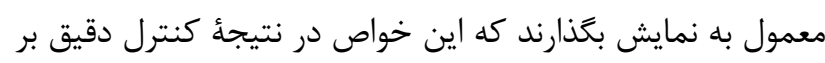

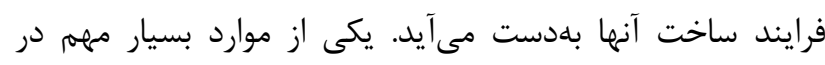

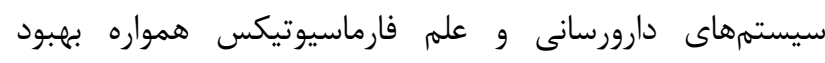

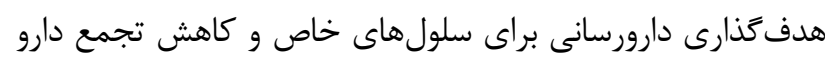

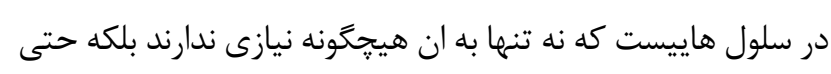

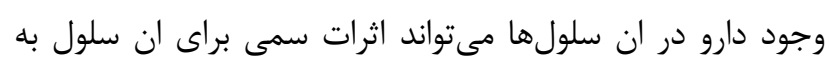

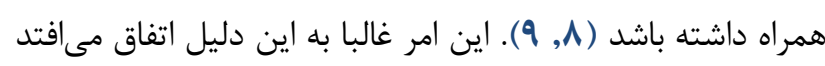

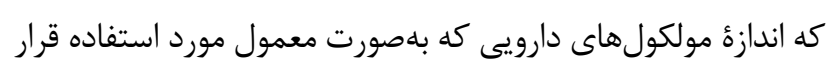

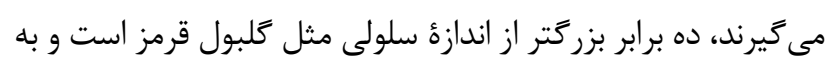

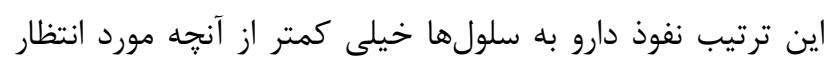

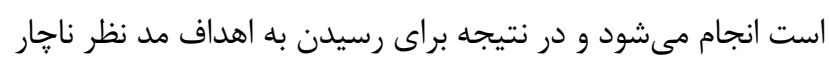

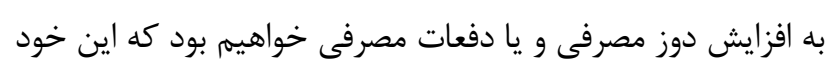

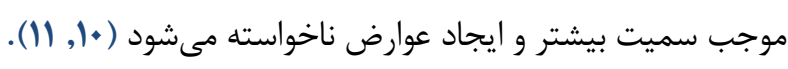

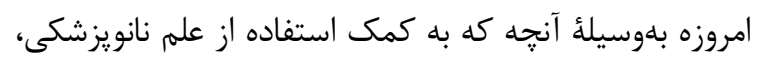

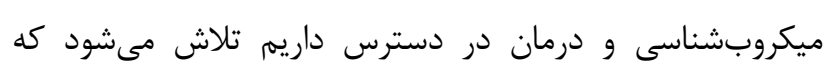

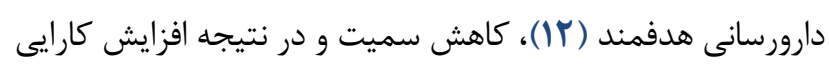

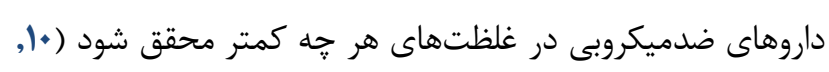

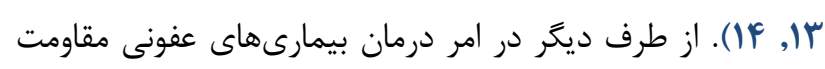

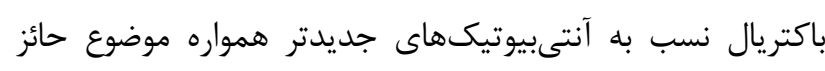

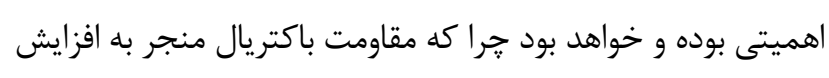

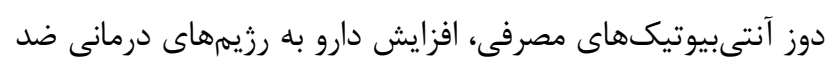

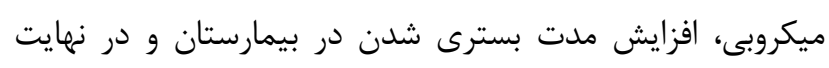

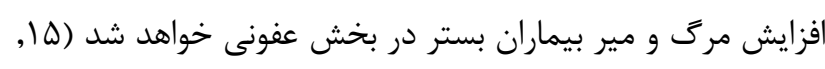

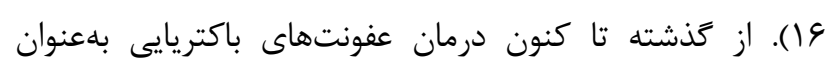

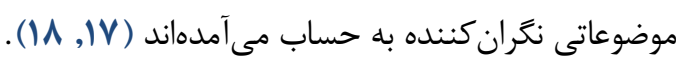
استفاده از نانوتكنولوزى بلوسيلة رويكردهاى متعددى كه تابه

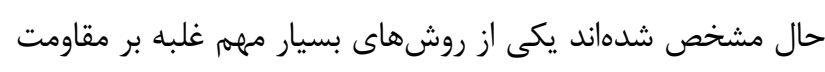

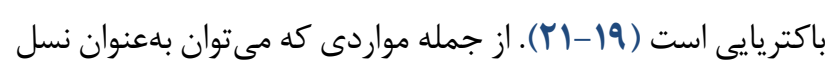

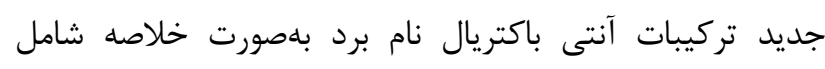
نانوذرات حاوى يليمرهاى زيستى مثل كيتوزان (YT) (Y)، نانوذرات

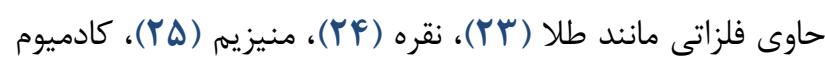

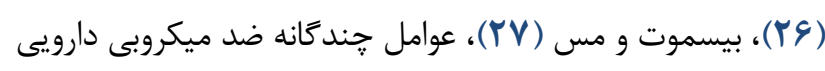
متصل شده به نانوذرات هستند (ها, \&1). ضرورت اين تحقيق ايجاد نانوساختارهايى كه در يايه يُليمرزيستى پيلى لاكتيك اسيد بهذهمراه 
سيكلهاى روشن- خاموش ז:ا قرارگرفت و رسوب نهايى از روى

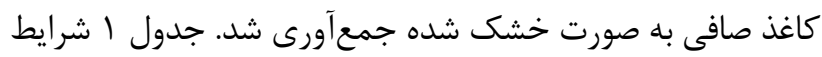

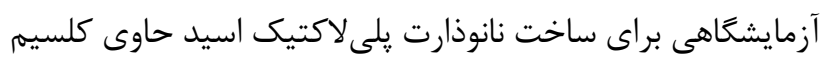
را نشان مى مهد.
A2 ، A1 مخلوط شد و نانوكاميوزيتهاى سنتز شده را به ترتيب

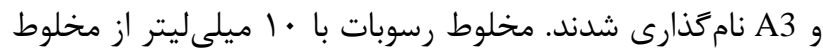

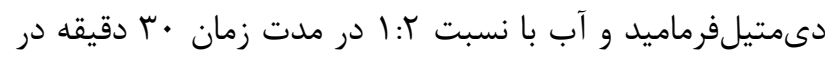

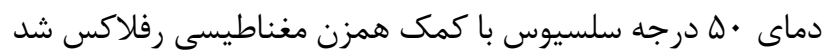

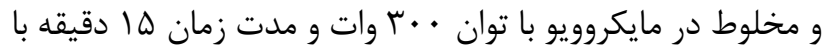
جدول ا. شرايط آزمايشعاهى براى ساخت نانوذرات بلى لاكتيك اسيد حاوى كلسيم

\begin{tabular}{|c|c|c|c|c|c|c|}
\hline شماره آزمايش & نام نانوذره & $\begin{array}{c}\text { PLA (َرم) } \\
\text { وزم) }\end{array}$ & 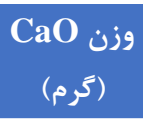 & حجم دىمتيلفر ماميد و آب & pH & 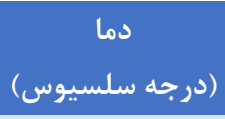 \\
\hline 1 & $\mathrm{~A}_{1}$ & $\cdot 10$ & $\cdot / r \Delta$ & $r$. & $1-9$ & $\Delta$. \\
\hline$r$ & $\mathrm{~A}_{2}$ & $\cdot / V \Delta$ & $\cdot 10$ & $r$. & $1-9$ & $\Delta$. \\
\hline r & $\mathrm{A}_{3}$ & 1 & 1 & $r \cdot$ & $1-9$ & $\Delta$. \\
\hline
\end{tabular}

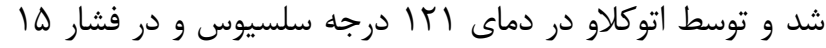
يوند بر اينج مربع به مدت ها دقيقه استريل شد. محيط كشت مولر

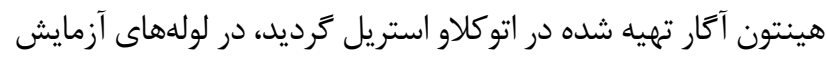
بزرگ به حجم \| ميلىليتر ريخته شدند. رقتهاى تهيهشده از نمونه

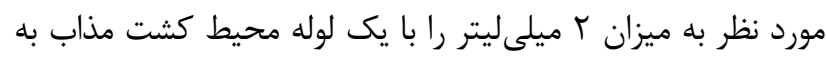
خوبى مخلوط كرده و به يليت منتقل شدند. به اين ترتيب رقتهاى

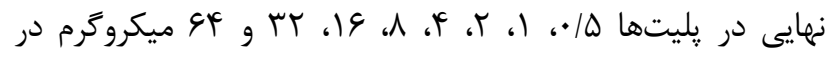
ميلىليتر شد. همجنين پيليتهاى كنترل منفى و مثبت نيز تهيه شد. يشت درب هيليتها از قبل از نظر غلظت ماده ضدميكروبى و محل كشت هر ميكروب به صورت واضح علامت قذارى شده بود. از باكترىهايى كه TY ساعت قبل كشت داده شده بودند در V لولهٔ مايع باقىمانده كه حاوى r ميلىليتر از محيط كشت مولر هينتون براث بودند سوسيانسيون ميكروبى ساخته شد كه از نظر كدروت مشابه مانه

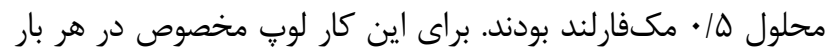
توسط شعله آتش استريل شد و يس از آن كه دمايش به حدى يه يايين آمد، كه به باكترىهاى زنده آسيبى وارد نكند كلونىهاى مورد نظر برداشته شدند و در محيط كشت مايع به خوبى براكنده شدند.

\section{يافتهها}

الكوى :يراش اشعه ايكس نمونئ نانوذرات تهيه شده از يلى لاكتيك اسيد حاوى كلسيم اكسايد در شكل ا مشاهده

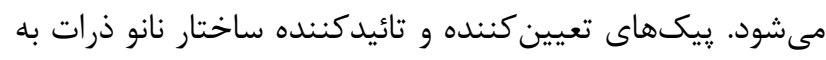
وضوح در طيف مشخص شده است. با استفاده از معادلله دباى شرر مىتوان اندازه ذرات را از طريق معادله زير حساب كرد:

$$
\mathrm{D}_{\mathrm{c}}=\mathrm{K} \lambda / \beta \cdot \cos \theta \quad \text { معادله }
$$

\section{روش تهيه محلول نيم مك فارلند}

I/IVD ه • ميلى ليتر از باريم كلرايد دو هيدراته با غلظت

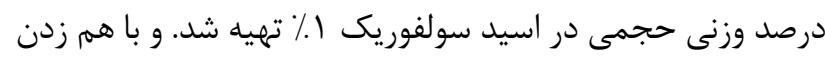
مداوم به خوبى به سوسيانسيون يك دستى تبديل شد. جِّالى

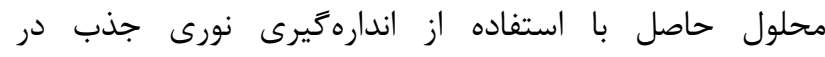

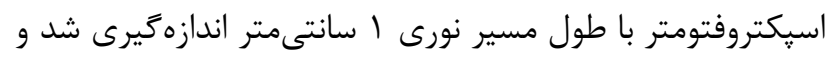

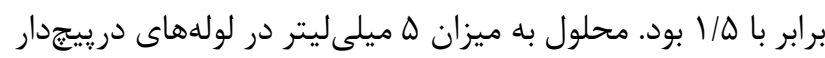

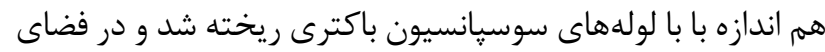

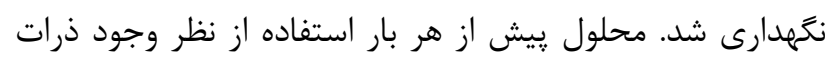

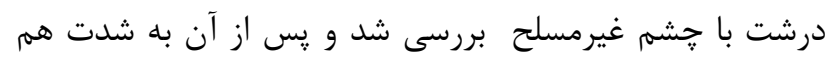
زده شد تا كدورت يكنواختى ايجاد شود. در سوسيانسيونى كه از

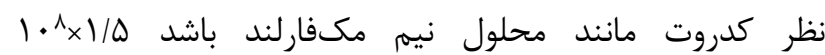
ميكروار Fانيسم وجود دارد.

\section{روش تهيه محيط كشت مولر هينتون آكار و مولر هينتون براث}

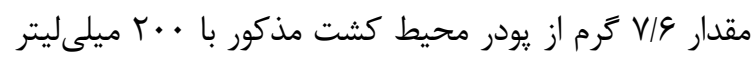
آب مقطر مخلوط شد و سيس توسط حرارت حل شد و حرارت دادن تا زمان شفاف شدن محلول ادامه يافت. سيس توسط يِيِت، ميلىليتر از اين محيط را برداشته و داخل لولههاى سرييجدار بزرى

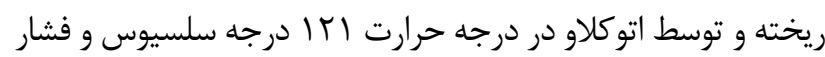
ها يوند بر اينج مربع به مدت ها دقديقه استريل شد. بعد از استريل كردن، اين محيط را با دو ميلىليتر از مخلوط تركيب سنتز شده و

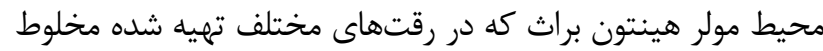

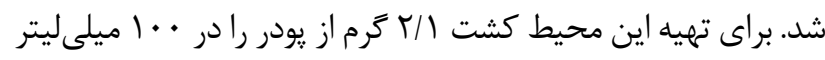
آب مقطر ريخته شد و به هم زده شد تا كه كاملا يودر حل شود. سيس

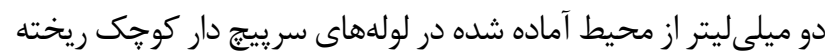




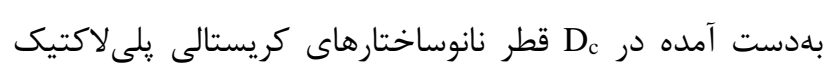

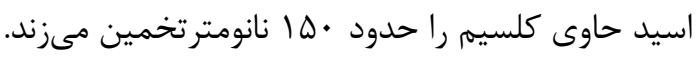

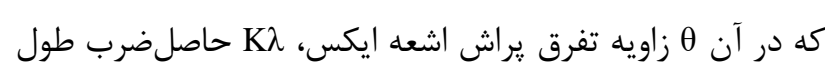

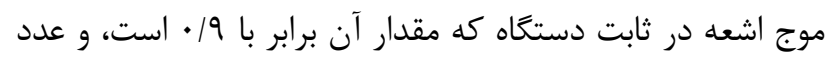

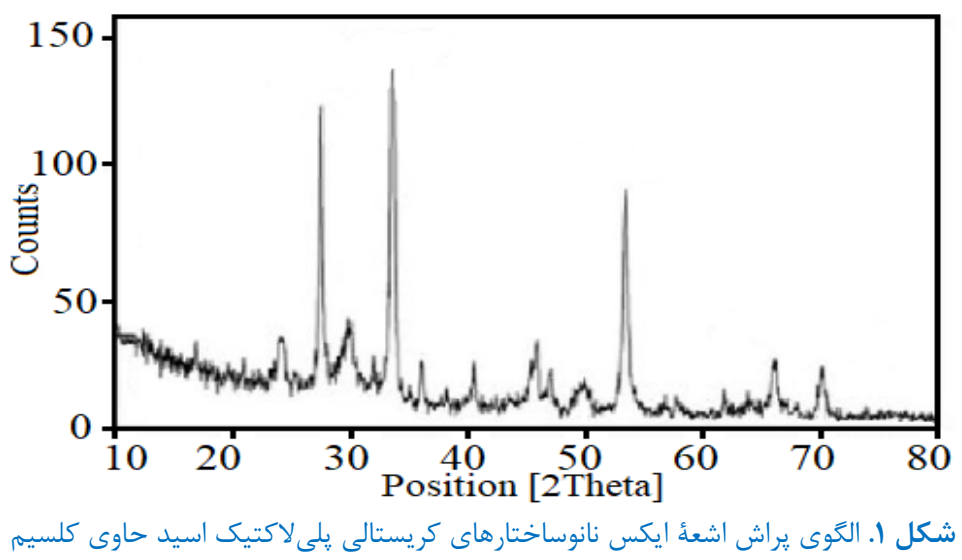

مى آيد. نتيجه بررسى اندازه ذرهاى تفرق ديناميك نور نمونه نانوذره بهمنظور بررسى اندازء دقيق نانوساختارها از دياگرام اندازه

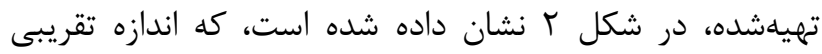

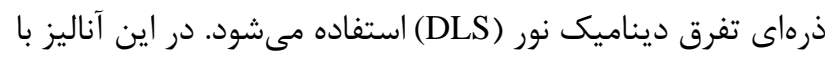

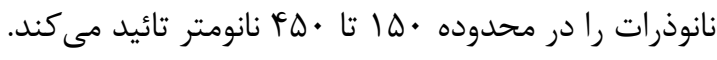

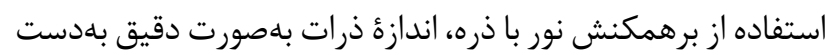

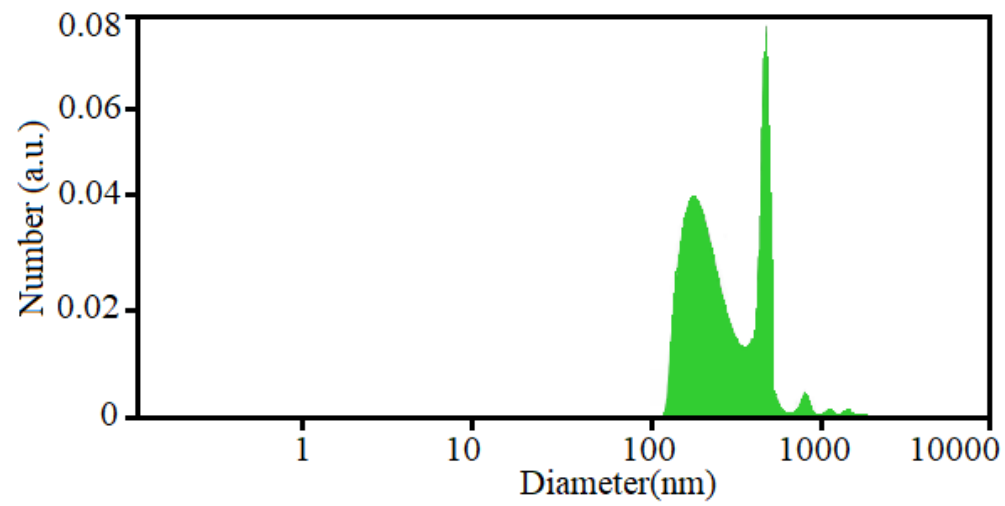

شكل r. دياگرام اندازه ذرهاى تفرق ديناميك نور نانوساختارهاى كريستالى بلى لاكتيك اسيد حاوى كلسيم

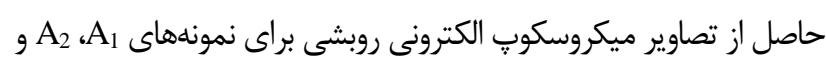

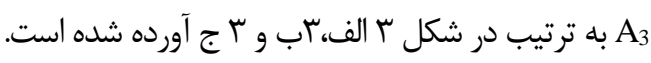

بامنظور بررسى ساختار سطحى و ويزگ هاى شكلى نانوساختارها تصويربردارى با استفاده از ميكروسكوٍ الكترونى روبشى انجام شد. نتايج
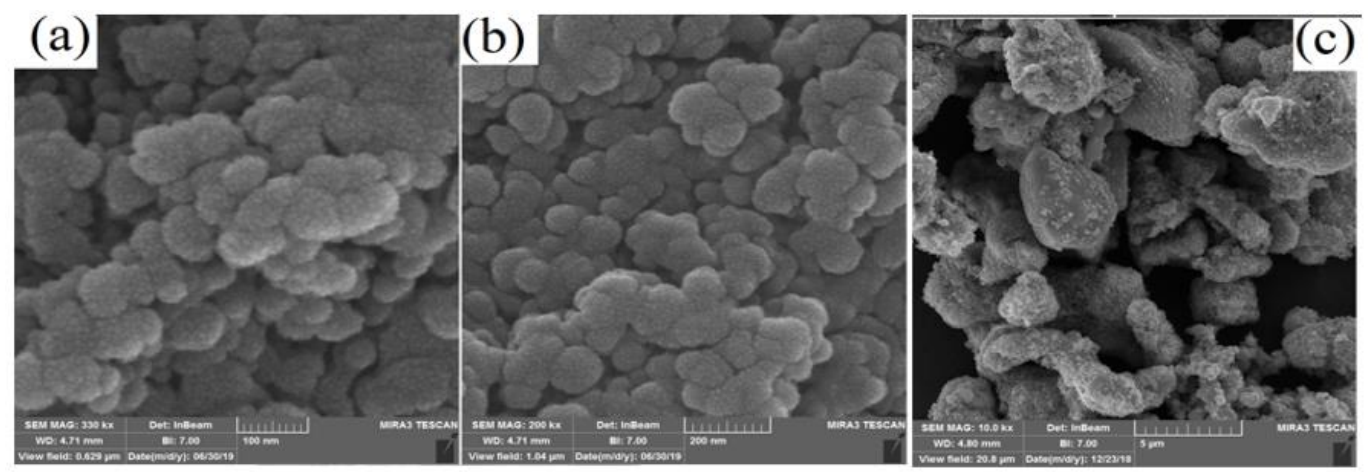

شكل ب. تصاوير ميكروسكوب الكترونى روبشى براى نمونهاى A A A و A A نانوساختارهاى كريستالى بلى لاكتيك اسيد حاوى كلسيم بترتيب الف، ب و ج 


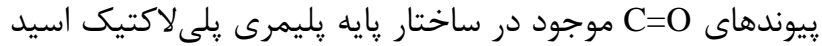
FT- در ناحيه $191 \mathrm{~V} \mathrm{~cm}$ نمايش داده شداند. وجود پيوندهاى فلزى Ca-O IR يلى لاكتيكاسيد در ناحيه زير ضعيفى نمايان مىشود. بdمنظور شناسايى گروههاى عاملى و پييوندهاى تشكيل شده بينساختارى از اسيكتروسكويى مادون قرمز (FT-IR) استفاده شد.

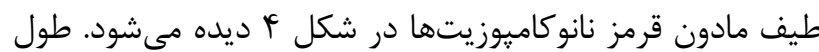

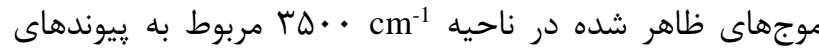
هيدروكسيدى گروه O-H در ساختار است. ييوندهاى C-C در طول موج حدود

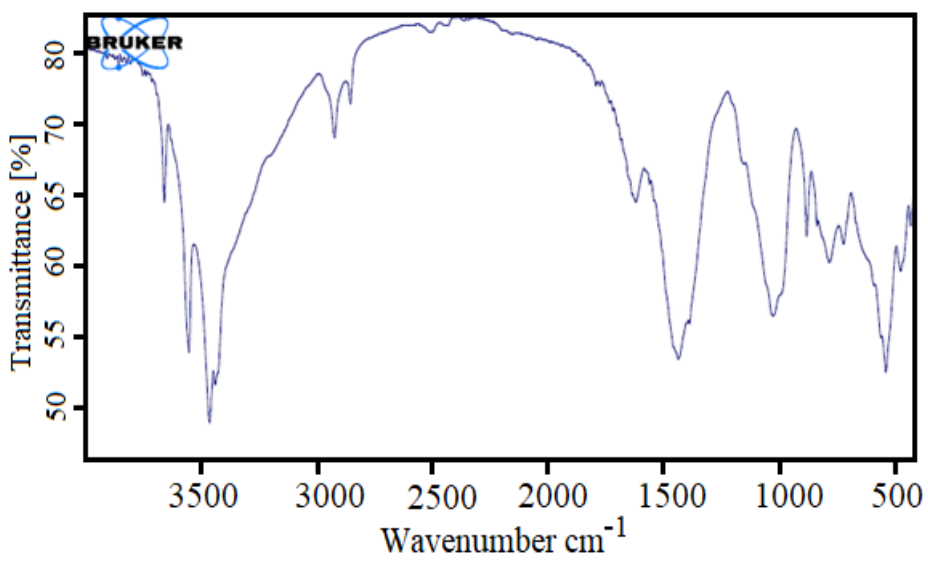

شكل f. اسيكتروسكويى مادون قرمز نانوساختارهاى كريستالى بلى لاكتيك اسيد حاوى كلسيم مربوط به نمونه

محيط كشت فاقد نمونه كه تلقيح ميكروب روى آن انجام شده و منظور از كنترل منفى، محيط كشت فاقد نمونه و تلقيح ميكروب است كه به صورت همزمان در تمامى آزمايشها كذاشته شدند. شكل ه مقايسه حداقل غلظت مهارى رشد در هر سه نانو كاميوزيت

$$
\text { را نشان مى مهد. }
$$

براى بررسى اثرات ضدميكروبى تركيبات سنتزشده از روش

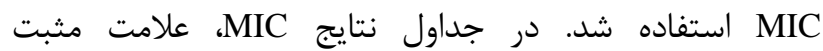
نشاندهنده رشد و علامت منفى نشان دهنده عدم رشد باكترى است. جدول r اثرات ضدميكروبى مربوط به نانوذرات A A با استفاده از روش MIC را نشان مى دهد. همجنين منظور از كنترل مثبت،

جدول r. نتايج حاصل رشد باكترىهاى استاندارد در ^ غلظت مختلف از نانوذرات A

\begin{tabular}{|c|c|c|c|c|c|c|c|c|c|}
\hline Bacteria & $\begin{array}{c}64 \\
\mu \mathrm{g} / \mathrm{mL}\end{array}$ & $32 \mu \mathrm{g} / \mathrm{mL}$ & $16 \mu \mathrm{g} / \mathrm{mL}$ & $8 \mu \mathrm{g} / \mathrm{mL}$ & $4 \mu \mathrm{g} / \mathrm{mL}$ & 2 & $\mu \mathrm{g} / \mathrm{mL}$ & $1 \mu \mathrm{g} / \mathrm{mL}$ & $0.5 \mu \mathrm{g} / \mathrm{mL}$ \\
\hline E. coli & - & - & - & - & - & & - & + & + \\
\hline K. pneumoniea & - & - & - & - & - & & + & + & + \\
\hline S. marcescens & - & - & - & - & + & & + & + & + \\
\hline$P$. aeruginosa & - & - & - & - & + & & + & + & + \\
\hline S. aureus & - & - & - & - & - & & + & + & + \\
\hline M. luteus & - & - & - & - & - & & - & - & + \\
\hline B. subtilis & - & - & - & - & - & & + & + & + \\
\hline Control + & + & + & + & + & + & & + & + & + \\
\hline Control - & - & - & - & - & - & & - & - & - \\
\hline
\end{tabular}




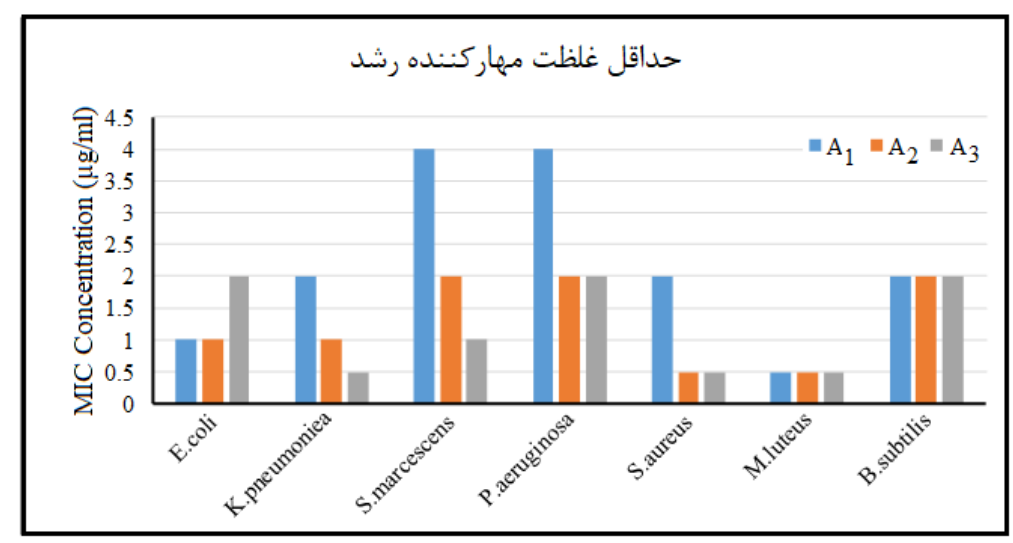

شكل ه. مقايسه حداقل غلظت مهارى رشد در هر سه نانوكاميوزيت

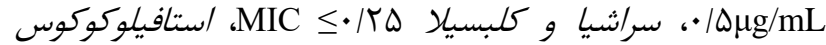
/ بيدرميديس إMg/mL

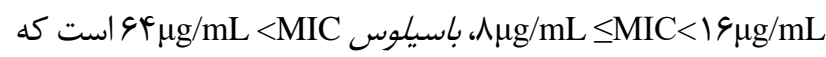
نسبت به نتايج بدست آمده در اين تحقيق داراى تاثيرات كمترى براسير

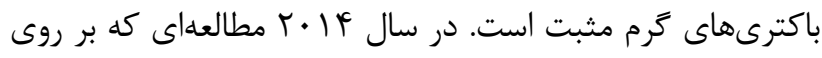

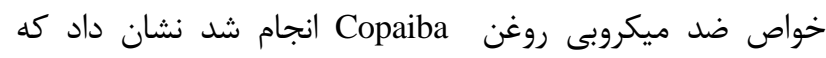

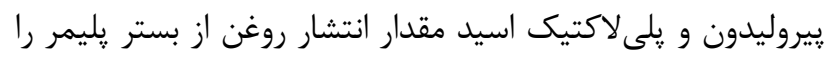

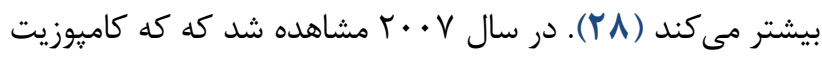

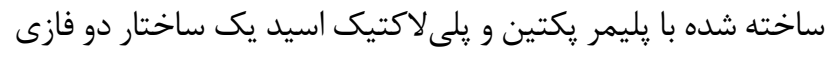

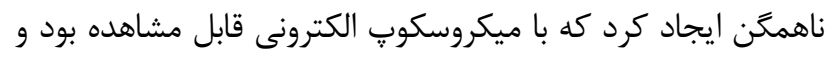

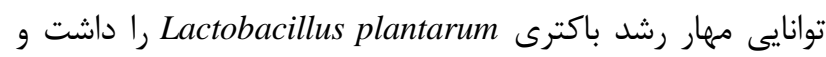

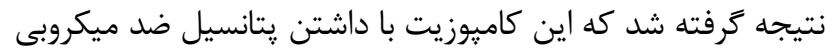

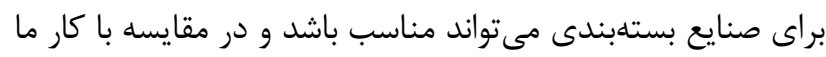

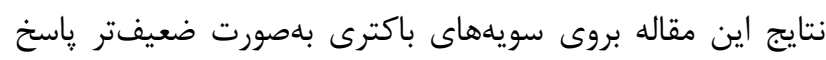

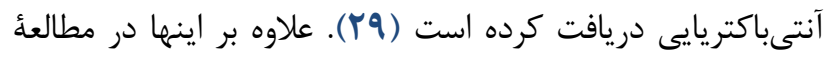

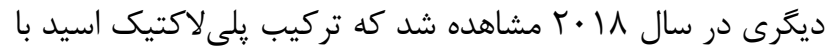

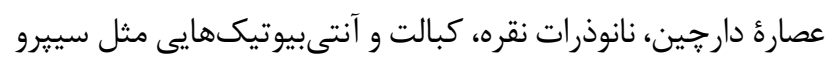

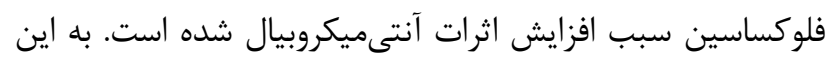

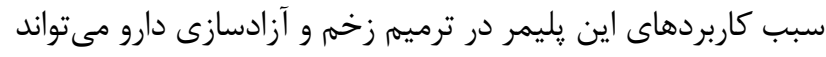

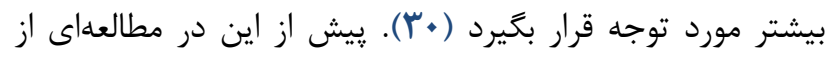

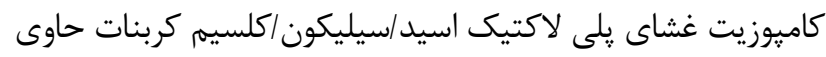

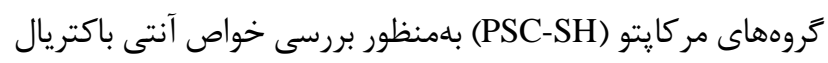

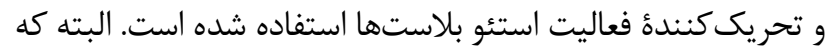

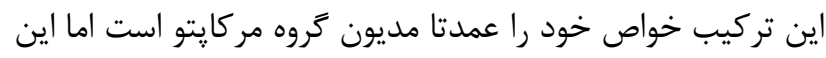

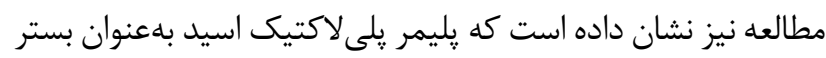

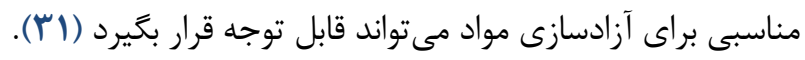
در مطالعه حاضر نيز با تركيب كردن غلظتهاى مختلف از نانوذرات فلزى كلسيم اكسيد در بستر يليمرى يلى لاكتيك اسيد
در سالهاى اخير مطالعه بر روى خواص ضد ميكروبى اكسيدات فلزى نتايج اميد بخشى نشان داده است. در اين مطالعه

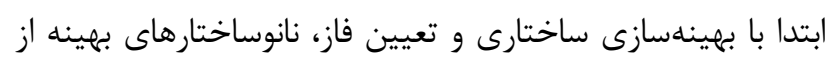

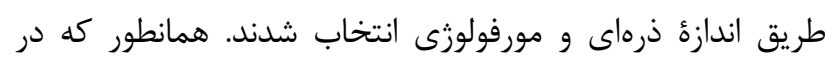

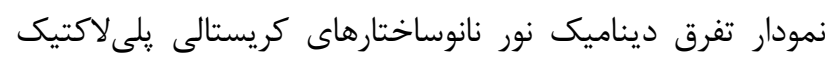

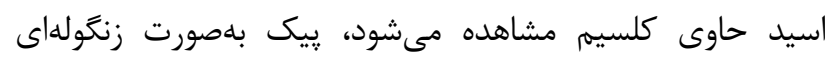

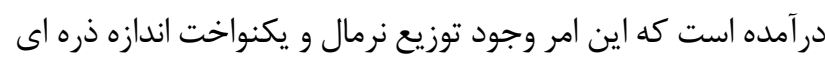

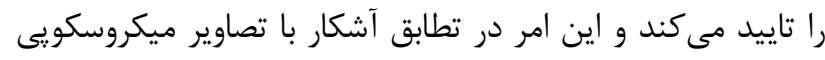

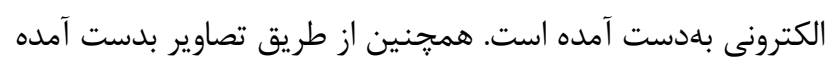

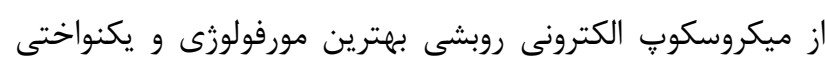

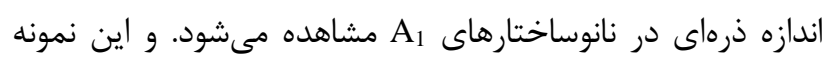

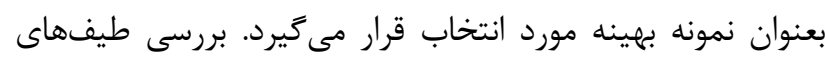

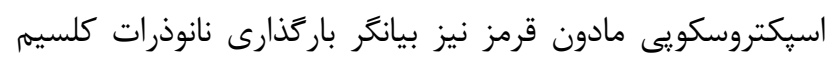

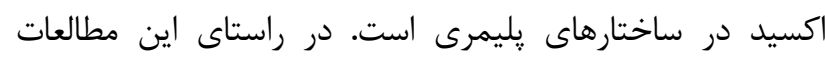

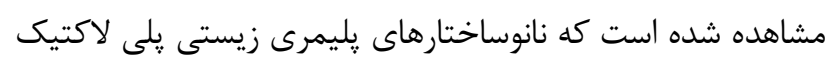

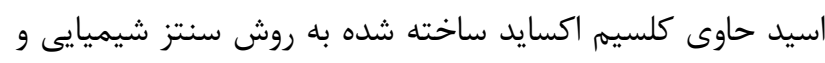

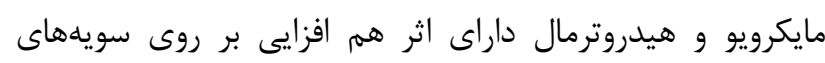

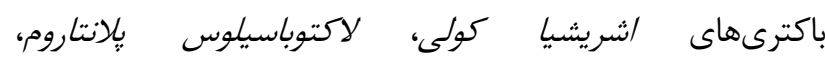

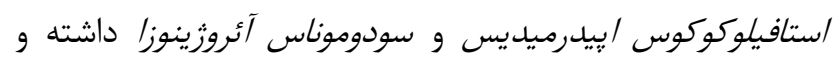

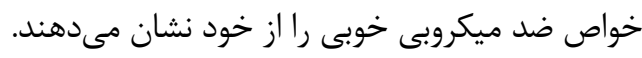

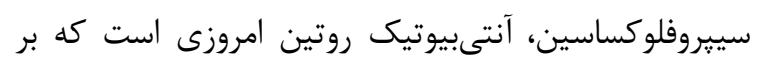

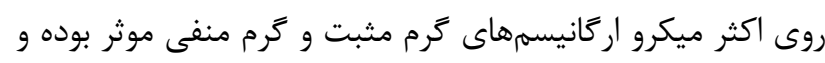

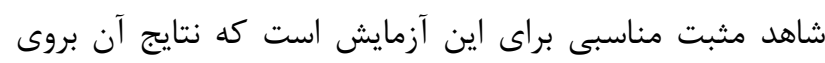

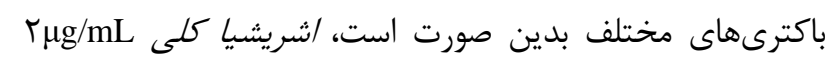

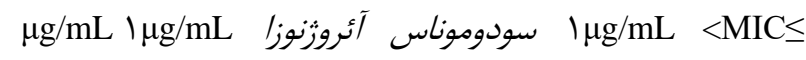

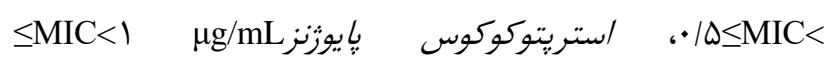




$$
\begin{aligned}
& \text { بيدا كرده است. به نظر مىرسد اين تركيب مىتواند براى } \\
& \text { فرمولاسيونهاى ترميم زخم مورد مطالعه قرار بخيرد. }
\end{aligned}
$$

$$
\text { نتيجهد گيرى }
$$

نانوساختارهاى زيستى يلى لاكتيكاسيد/كلسيم اكسايد با.

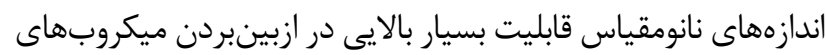

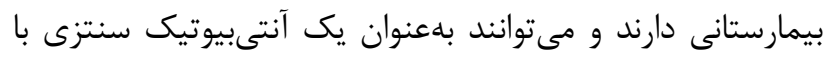
كارايى بالا در صنعت داروسازى مورد استفاده قرار بخيرند.

\section{سباسَز ارى}

بدينوسيله، از مركز تحقيقات فارماسيوتيكس دانشعاه علوم يزشكى كرمان و همجنين كميتهُ تحقيقات دانشجويى اين دانشعاه بهدليل همكارى لازم كه در انجام اين يروزه تحقيقاتى داشتند كمال تشكر را داريم.

$$
\text { تعارض در منافع }
$$

اين مقاله يزوهشى مستقل است كه بدون حمايت مالى سازمانى انجام شده است. در انجام مطالعهُ حاضر، نويسندكان هيجزَنه تضاد منافعى نداشتهاند.

\section{Referance}

1. Bhushan B. Introduction to nanotechnology. Springer handbook of nanotechnology: Springer; 2010. p. 1-13. [DOI:10.1007/978-3-642-02525-9_1]

2. Golabiazar R, Othman KI, Khalid KM, Maruf DH, Aulla SM. Green Synthesis, Characterization, and Investigation Antibacterial Activity of Silver Nanoparticles Using Pistacia atlantica Leaf Extract. Bionanoscience. 2019;9(2):323-33. [DOI:10.1007/s12668-019-0606-z]

3. Allahverdiyev AM, Abamor ES, Bagirova M, Rafailovich MJFm. Antimicrobial effects of $\mathrm{TiO} 2$ and $\mathrm{Ag} 2 \mathrm{O}$ nanoparticles against drug-resistant bacteria and leishmania parasites. Future Microbiol. 2018; 4 (4):113123.

4. Khanipour A, Bahmani Z, Oromiehie A, Motalebi AJ. Effect of packaging with nano-composite clay/LDPE film on the quality of rainbow trout (Oncorhynchus mykiss) fillet at refrigerated storage. IRAN J FISH SCI. 2020;19(2):698-714.

5. Cao F, Ju E, Zhang Y, Wang Z, Liu C, Li W, et al. An efficient and benign antimicrobial depot based on silver-

$$
\begin{aligned}
& \text { سعى بر آن شد كه اثرات ميكروبى مقايسه شود. همانطور كه نتايج } \\
& \text { نشان مىدهد، تمامى غلظتها توانستند بر روى VIC }
\end{aligned}
$$

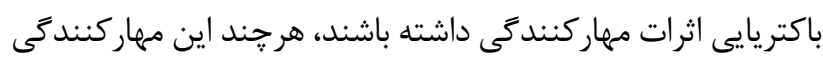

$$
\begin{aligned}
& \text { از الكوى ثابت و مشخصى بيروى نكرده است. } \\
& \text { در مطالعهاى كه انجام شد سه غلظت متفاوت از نانوذرات }
\end{aligned}
$$

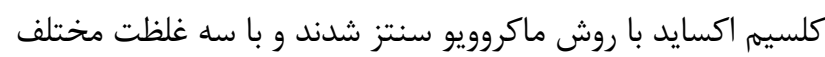

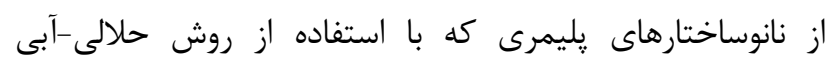

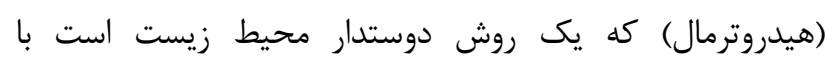

$$
\begin{aligned}
& \text { نسبتهاى مشخص تركيب شدند و مورد شناسايى ساختارى و }
\end{aligned}
$$

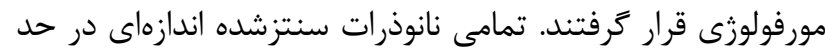

$$
\begin{aligned}
& \text { نانومتر داشتند ولى از لحاظ توزيع يراكندگى و ويزگى هاى سطحى } \\
& \text { با هم تفاوت داشتند. و يراكند }
\end{aligned}
$$

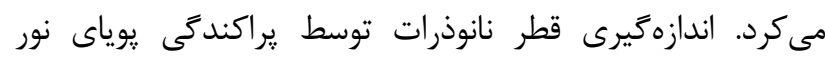

$$
\begin{aligned}
& \text { باهوسيلة تصاوير ميكروسكوب الكترونى تاييد شد. در تمامى غلظتها } \\
& \text { اثرات مهارى رشد بر روى باكترىهاى مورد آزمايش مشاهده شد. }
\end{aligned}
$$

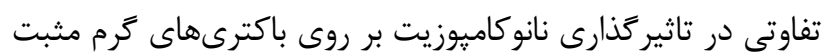

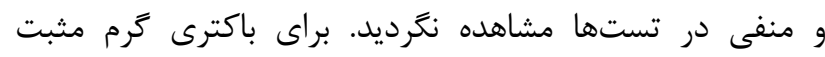

$$
\begin{aligned}
& \text { باسيلوس سابتيليس با افزايش درصد وزنى كلسيهم اكسايد محدوده } \\
& \text { ثابت ماند و تاثير افزايش غلظت ماده ضدميكروبى مشاهده }
\end{aligned}
$$

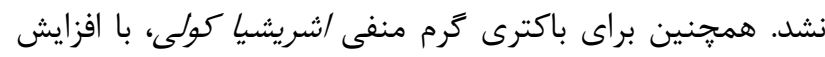

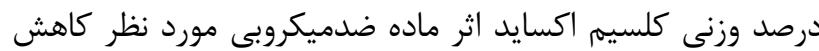

infused MoS2. ACS Nano. 2017;11(5):4651-9. [DOI:10.1021/acsnano.7b00343] [PMID]

6. Shi L-E, Li Z-H, Zheng W, Zhao Y-F, Jin Y-F. Synthesis, antibacterial activity, antibacterial mechanism and food applications of $\mathrm{ZnO}$ nanoparticles: a review. Food additives \& contaminants. Part A. 2014;31(2):173-86. [DOI:10.1080/19440049.2013.865147] [PMID]

7. Naito M, Yokoyama T, Hosokawa K, Nogi K. Nanoparticle technology handbook: Elsevier; 2018.

8. Heidari AJMJOC. Vibrational biospectroscopic studies on anti-cancer nanopharmaceuticals (Part II). Nanomed. 2018;20(1):74-117.

9. Yousefshahi H, Aminsobhani M, Shokri M, Shahbazi RJEjotm. Anti-bacterial properties of calcium hydroxide in combination with silver, copper, zinc oxide or magnesium oxide. Eur J Transl Myol. 2018;28 (4): 22-28. [DOI:10.4081/ejtm.2018.7545] [PMID] [PMCID]

10. Silva GA. Introduction to nanotechnology and its applications to medicine. Surg Neurol. 2004;61(3):21620. [DOI:10.1016/j.surneu.2003.09.036] [PMID] 
11. Raghupathi KR, Koodali RT, Manna ACJL. Sizedependent bacterial growth inhibition and mechanism of antibacterial activity of zinc oxide nanoparticles. Langmuir. 2011;27(7):4020-8. [DOI:10.1021/la104825u] [PMID]

12. Honary S, Zahir FJTJoPR. Effect of zeta potential on the properties of nano-drug delivery systems-a review. AJOL. 2013;12(2):265-73. [DOI:10.4314/tjpr.v12i2.20]

13. Nanoparticle-Based Medicines: A Review of FDAApproved Materials and Clinical Trials to Date. Pharm Res. 2016;33(10):2373-87. [DOI:10.1007/s11095-0161958-5] [PMID]

14. Bobo D, Robinson KJ, Islam J, Thurecht KJ, Corrie SRJPr. Nanoparticle-based medicines: a review of FDAapproved materials and clinical trials to date. Pharm Res. 2015;34(9): 71-89.

15. Pelgrift RY, Friedman AJ. Nanotechnology as a therapeutic tool to combat microbial resistance. Adv Drug Deliv Rev. 2013;65(13):1803-15. [DOI:10.1016/j.addr.2013.07.011] [PMID]

16. Pelgrift RY, Friedman AJJAddr. Nanotechnology as a therapeutic tool to combat microbial resistance. 2013;65(13-14):1803-15. [DOI:10.1016/j.addr.2013.07.011] [PMID]

17. Shorr AFJCcm. Review of studies of the impact on Gramnegative bacterial resistance on outcomes in the intensive care unit. Crit Care Med. 2009;37(4):1463-9. [DOI:10.1097/CCM.0b013e31819ced02] [PMID]

18. Zaidi S, Misba L, Khan AUJNN, Biology, Medicine. Nano-therapeutics: a revolution in infection control in post antibiotic era. Nanomedicine. 2017;13(7):2281-301. [DOI:10.1016/j.nano.2017.06.015] [PMID]

19. ALrawashdeh IN, Qaralleh H, Al-limoun MO, Khleifat KMJapa. Antibactrial Activity of Asteriscus graveolens Methanolic Extract: Synergistic Effect with Fungal Mediated Nanoparticles against Some Enteric Bacterial Human Pathogens. J. basic appl. Res biomed. 2019;5(2): 89-98.

20. Basavalingaiah K, Harishkumar S, Nagaraju GJF. Uniform deposition of silver dots on sheet like BiVO4 nanomaterials for efficient visible light active photocatalyst towards methylene blue degradation. FlatChem. 2020;19 (4):113-142. [DOI:10.1016/j.flatc.2019.100142]

21. Lam SJ, Wong EH, Boyer C, Qiao GGJPips. Antimicrobial polymeric nanoparticles. Progress in Poly. Sci. [DOI:10.1016/j.progpolymsci.2017.07.007]

22. Rahman PM, Mujeeb VA, Muraleedharan K, Thomas SKJAJoC. Chitosan/nano ZnO composite films: enhanced mechanical, antimicrobial and dielectric properties. Arab. J. Chem. 2018;11(1):120-7. [DOI:10.1016/j.arabjc.2016.09.008]
23. Zheng K, Setyawati MI, Leong DT, Xie JJAn. Antimicrobial gold nanoclusters. ACS Nano. 2017;11(7):6904-10. [DOI:10.1021/acsnano.7b02035] [PMID]

24. Shahriary M, Veisi H, Hekmati M, Hemmati SJMS, C E. In situ green synthesis of Ag nanoparticles on herbal tea extract (Stachys lavandulifolia)-modified magnetic iron oxide nanoparticles as antibacterial agent and their 4nitrophenol catalytic reduction activity. Mater. Sci. Eng. C. 2018;90:57-66. [DOI:10.1016/j.msec.2018.04.044] [PMID]

25. Vergheese M, Vishal SKJJPP. Green synthesis of magnesium oxide nanoparticles using Trigonella foenumgraecum leaf extract and its antibacterial activity. Int. J. Pharmacogn. Phytochem. 2018;7:1193-200.

26. Abd Elsalam SS, Taha RH, Tawfeik AM, El-Monem A, Mohamed O, Mahmoud HAJTEJoHM. Antimicrobial activity of bio and chemical synthesized cadmium sulfide nanoparticles. Egypt. J. Hosp. Med. 2018;70(9):1494-507. [DOI:10.12816/0044675]

27. Lv Q, Zhang B, Xing X, Zhao Y, Cai R, Wang W. Biosynthesis of copper nanoparticles using Shewanella loihica PV-4 with antibacterial activity: Novel approach and mechanisms investigation. J Hazard Mater. 2018;347:141-9. [DOI:10.1016/j.jhazmat.2017.12.070] [PMID]

28. Bonan RF, Bonan PR, Sampaio FC, Albuquerque AJ. In vitro antimicrobial activity of solution blow spun poly (lactic acid)/polyvinylpyrrolidone nanofibers loaded with Copaiba (Copaifera sp.) oil. Mat. Sci. Eng. Matt. 2015;48:372-7. [DOI:10.1016/j.msec.2014.12.021] [PMID]

29. Liu L, Finkenstadt V, Liu CK, Jin T, Fishman M, Hicks KJJoAPS. Preparation of poly (lactic acid) and pectin composite films intended for applications in antimicrobial packaging. J. Appl. Polym. Sci. 2007;106(2):801-10. [DOI:10.1002/app.26590]

30. Scaffaro R, Lopresti F, Marino A, Nostro A. Antimicrobial additives for poly (lactic acid) materials and their applications: current state and perspectives. Biotech. 2018;102(18):7739-56. [DOI:10.1007/s00253-018-92201] [PMID]

31. Tokuda S, Obata A, Kasuga T. Preparation of poly(lactic acid)/siloxane/calcium carbonate composite membranes with antibacterial activity. Acta Biomaterialia. 2009;5(4):1163-8 [DOI:10.1016/j.actbio.2008.10.005] [PMID]

32. Niakan S, Niakan M, Hesaraki S, Nejadmoghaddam MR, Moradi M, Hanafiabdar M, et al. Comparison of the Antibacterial Effects of Nanosilver With 18 Antibiotics on Multidrug Resistance Clinical Isolates of Acinetobacter baumannii. Jundishapur J Microbiol. 2013;6(5):e8341. [Article] [DOI:10.5812/jjm.8341] 